\title{
Conventional and Molecular Characterization of Sheep Poxvirus Dakahlia Governorate, Egypt
}

Hagar E. Ghander*, Mohamed S. El-Tholoth, Sahar E. Abd-El Rahman, Ali A. El-Kenawy

Department of Virology, Faculty of Veterinary Medicine, Mansoura University, Mansoura, Egypt

\section{ARTICLE HISTORY}

Received: 23.06 .2020

Revised: 13.08 .2020

Accepted: 21.08 .2020

Hagar E. Ghander*; Tel.01276002831 , Email hagarghander440@gmail.com

ORCID: $\quad$ https://orcid.org/0000-00025253-5168

\author{
ABSTRACT \\ Objective: Isolation, conventional and molecular characterization of sheep poxvirus \\ (SPV) from clinically diseased vaccinated sheep in Dakahlia Governorate, Egypt. \\ Design: Descriptive study. \\ Samples: Forty samples including 20 skin nodules and 20 from lung, liver, lymph node \\ and tongue (5samples from each) were collected from sheep flock consisted of 25 adult \\ and 5 lambs.
}

Procedures: The suspected virus was isolated through embryonated chicken eggs (ECEs). SPV was detected by agar gel precipitation test (AGPT), indirect fluorescence antibody test (IFAT) and histopathology in field and egg passaged samples. Ten samples were selected for molecular characterization by conventional and real time polymerase chain reaction (PCR) and for sequence analysis based on P32 gene.

Results: The disease prevalence was $16.7 \%$ (5 infected). Thirty-two samples (80\%) recorded positive isolation of SPV ( kin nodules, $n=16$; lung, $n=5$; lymph node, $n=5$; liver, $\mathrm{n}=3$; tongue, $\mathrm{n}=3$ ). The positive results percentage for AGPT and IFAT in field samples was $42.5 \%$ and $92.5 \%$, respectively. In egg passaged samples, $82.5 \%$ of samples showed positivity by IFAT. Intra- cytoplasmic inclusions were detected in $75 \%$ of field samples, and in $62.5 \%$ of egg passaged samples. All selected samples for the virus molecular detection showed positive results. P32 gene sequence analysis revealed that our SPV was closely related to Saudi Arabia virus, 2019.

Conclusion and clinical relevance: SPV detected from clinically diseased vaccinated sheep in Egypt. So further study is crucial to identify the reason for vaccination failure and also on precise determination of this virus origin as well as virus spread pattern analyses.

Keywords: Agar gel precipitation test (AGPT); histopathology; indirect fluorescence antibody test (IFAT); nucleotide sequence analysis; polymerase chain reaction (PCR); real time-PCR; sheep poxvirus (SPV); virus isolation.

\section{INTRODUCTION}

Sheep pox (SP) is the severest and most contagious viral disease in sheep [1]. SP is characterized clinically by fever, anorexia, depression, appearance of pox lesions on wool free areas, development of lung lesions and enlargement of superfacial lymph nodes [2]. The disease is caused by sheep poxvirus (SPV), a member in genus Capripoxvirus, subfamily Chordopoxvirinae, family Poxviridae, order Chitovirales, class Pokkesviricetes, phylum Nucleocytoviricota, kingdom Bamfordvirae, realm Varidnaviria. The other members of Capripoxvirus genus are goat poxvirus (GPV) and lumpy skin disease virus (LSDV) [3].

Sheep and goats are susceptible to SP and GP, whereas some strains are pathogenic for sheep only, other strains are pathogenic for goat only and the remaining strains can cause illness in both sheep and goats [4].
Sheep poxvirus (SPV) is double-stranded DNA enveloped brick shaped with complex capsid symmetry, the external surface consists of protein and lipid surrounding the core and two lateral bodies. The core is biconcave, in other words dumbbell-shaped. The genome ends consist of a terminal hairpin loop "no free ends" with many tandem repeated sequences included within the inverted terminal repeats (ITRs) [5].

Sheep pox had been described in Europe since the first century. It was reported in England, France, Italy and Germany during the $13^{\text {th }}$ century [6]. In Egypt, a proof of circulating SPV strains was confirmed during 2014-2017 $[7,8,9]$.

There is large scale of SPV prevalence was recorded globally ranging from $100 \%$ to $5.18 \%$. In Egypt, previously recorded prevalence was $23.5 \%$ in 2017 [9,10,11,12]. 
SP is leading to strong financial losses in sheep industry in the form of high morbidity and mortalities, short-term death from advanced pneumonia and severe inflammation accompanied by reduced milk production, live loss of weight, increased rates of abortion, wool and leather loss and damage [13].So early diagnosis of SPV has been taken into account. SPV is diagnosed on the basis of clinical symptoms, isolation of the virus, conventional and molecular detection methods[14].

The conventional methods used in diagnosis of SPV include virus isolation, indirect fluorescent antibody test (IFAT), virus neutralization test, agar gel precipitation, latex agglutination and an antigen trapping enzyme-linked immunoasorbent

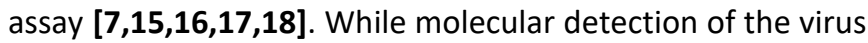
could be performed by conventional and real timepolymerase chain reaction $(P C R)[19,20]$.

P32 gene commonly used as a target for molecular characterization of the virus because its encoded protein contains the most significant antigenic determinant present in all strains of capripoxvirus [21].

The present work focused on isolation of SPV from vaccinated sheep in Egypt by using ECEs and identification of SPV antigen by using AGPTand IFAT in field and egg-passaged samples and molecular detection and characterization of identified SPV as well as, histopathological examination in field and egg-passaged samples.

\section{MATERIALS AND METHODS}

\subsection{Samples Collection and Preparation}

Forty samples in total, of which 20 skin nodules and 20 internal organs samples including "lung, liver, lymph node and tongue" (5samples from each organ) were collected from vaccinated sheep. Diseased animals exhibited multiple skin nodules in area free from wall as in the face (especially around the nostril and eyes), neck and under tail (Figure $1 \mathrm{~A}$ and B). Post mortem exammination revealed generalized nodules in internal organs (lung and tongue), congestion of liver and enlargement of superfacial lymph nodes (Figure $\mathbf{1} \mathbf{C}$ and D).

Negative control samples of skin biopsies, lung, liver, lymph node and tongue from healthy and non-vaccinated sheep have been collected. Each sample was split into three portions; the first portion kept in $10 \%$ neutral formalin for histological examination, the second portion was taken to the cryostat slide preparation freezing chamber for IFAT, and the third portion was placed into a sterilized plastic container with phosphate buffer saline (PBS) and antibiotics then put into an ice box for transportation to the virology laboratory and stored at $-02^{\circ} \mathrm{C}$ until used for isolation and characterization of the virus. Samples used for virus isolation were prepared in accordance with [22] as follows: by using sterile scissors, the samples were cut then ground into a sterile pestle and mortar containing sterile sand. The tissues were prepared with PBS containing antibiotics, making $20 \%$ suspension. Then for three times, they were frozen and thawed. After that the suspensions were centrifuged for 10 minutes at $3000 \mathrm{rpm}$. Finally, the supernatant was taken and preserved at $-20^{\circ} \mathrm{C}$ until usage.

\subsection{Preparation of Rabbit Hyperimmune Serum against SPV Vaccine}

Preparation of hyperimmune serum was carried out in accordance with [22] as follows: Four $\mathrm{ml}$ sterile PBS were added to each lyophilized live SPV vaccine vial of $10^{5.2}$ $\mathrm{TCID}_{50} / \mathrm{ml}$ titer. Four rabbits were inoculated $\mathrm{S} / \mathrm{C}$ in two different sites four times at 2-weeks interval. One $\mathrm{ml}$ of live SPV vaccine was emulsified in $1 \mathrm{ml}$ Freund complete adjuvant in each injection. Fourteen days after the last injection, the rabbits were bled out and the blood was centrifugated for 10 minutes at $3000 \mathrm{rpm}$ for separation the hyperimmune serum and the hyperimmune serum preserved at $-20 \circ \mathrm{C}$ until used. The $5^{\text {th }}$ rabbit not injected and separated from the remaining rabbits for collection of a negative serum sample. The total protein concentration was estimated by spectrophotometer using the readymade kits compared to the non-inoculated rabbit.

\subsection{Reference SPV vaccine}

Lyophilized Kenyan sheep poxvirus strain (SPV) containing 50 doses with a titre of $\left(10^{5.2} \mathrm{TCID}_{50} / \mathrm{ml}\right)$ was obtained from Pox Department, Veterinary Serum and Vaccine Research Institute (VSVRI) Abbasia, Cairo, Egypt). The vaccine was reconstituted according to the manufacturer by adding $4 \mathrm{ml}$ PBS to be used for preparation of hyperimmune serum and as a positive control for identification of the suspected virus by AGPT and PCR.

\subsection{Inoculation of the prepared samples on chorioallantoic membrane (CAM ) of ECES}

The inoculation of the samples was carried out in accordance with [23] as follows: ECEs had been incubated in a forced ventilation, managed humidity egg incubator for a period of 11 days at $37 \circ \mathrm{C}$, and turned two times a day before inoculation. Piercing ahole at the center of air sac was carried out. By using air bulb, the air was suctioned through egg's blunt end to create false air sac beneath egg's lateral walls. $0.2 \mathrm{ml}$ of the inoculum was inoculated through the hole of the false aor sac. The holes were sealed with molten wax, then inoculated eggs were incubated in horizontal position at $37^{\circ} \mathrm{C}$. The eggs have been candled every day and the non specific eggs ,containing dead embryos in the first $24 \mathrm{hrs}$, were rejected. Finally, the CAMs after 5 days of incubation were collected, washed and examined for presence of pock lesions. For each sample, six passages were performed.

\subsection{Detection of SPV antigen using AGPT}

The detection of the suspected SPV by using AGPT in field samples and $6^{\text {th }}$ egg passaged samples was carried out in accordance with [14] as follows: the gel has been prepared by dissolving $1.5 \%$ agarose in PBS then autoclaved for 15 minutes. Ten $\mathrm{ml}$ of the agarose was put into a $5 \mathrm{~cm}$ in diameter petri dish and left to solidify at room temperature. A pattern of wells, consisting of six peripheral wells surrounding a central well ( $3 \mathrm{~mm}$ in diameter and $2 \mathrm{~mm}$ apart) 
was punched in the agar, when the agar has set. The suction device removed the agarose blocks and a little amount of the liquid agarose was used for sealing the wells by spilling into the bottom of all wells. The central well was filled with the hyperimmune serum and the peripheral wells were filled with the prepared field samples, $6^{\text {th }}$ egg passaged samples, control positive SPV and a control negative SPV. Dishes were incubated at $37^{\circ} \mathrm{C}$ for 5 days in humidified chamber and subsequently tested to detect the positive results in the form of precipitation lines.

\subsection{Detection of SPV antigen using IFAT}

It was appplied in accordance with [24] as following: the collected field samples, the CAMs of ECEs after the $6^{\text {th }}$ passage as well as the negative control samples (non-infected tissues and CAMs) were transferred to the cryostat freezing chamber and preserved at $-30{ }^{\circ} \mathrm{C}$ for 5 minutes. By using a cryostat knife, samples were sectioned at a thickness of 3 microns, then passed to glass slides. These sections remained for 20 minutes untill drying in air. Cold acetone used for fixation of the sections for 10 minutes. After that, the sections were washed with PBS. In a humidified chamber, the slides were incubated with a few drops of diluted prepared hyperimmune serum for 1 hour at 37 으, then washed with PBS ( $\mathrm{pH} 7.2$ ) for 3 times (10 minutes for each time). Then the slides were incubated in dark humidified chamber for 30 minutes at 37 o $C$ with a few drops of anti-rabbit FITC conjugate of 1:300 dilution then thoroughly washed three times, for 15 minutes (5 minutes for each time), then mounted with glycerol.The slides were covered with coverslip and examined by the fluorescent microscope. The positive results indicated by yellowish green color.

\subsection{Molecular Detection of SPV using conventional PCR}

Ten samples ( 6 field samples and 4 egg passaged samples) were selected for molecular detection and identification of SPV.

\subsubsection{DNA Extraction}

Extraction of DNA was done by using a commercial kit (Qiagen, Valencia, Calif., and USA- Catalog No.52904) in accordance with the kit handbook procedures and [25].

\subsubsection{Oligonucleotide primers}

The primers used in PCR reactions (B68\& B69) were designed according to [19] for partial amplification of P32 gene of SPV and manufactured by Sigma Chemical Company, USA. Lyophilized primers were resuspended in Tris/EDTA buffer till reach $100 \mu \mathrm{M}$ final concentration to amplify a 390 bp specific fragment.

\subsubsection{PCR amplification and gel electrophoresis}

The PCR was carried out using a Qiagen commercial PCR kit for amplification of $\mathrm{P} 32$ gene.The reaction mixture contained $2.5 \mu \mathrm{l}$ of $10 \mathrm{X}$ PCR Buffer, $1.5 \mu \mathrm{l}$ of $50 \mathrm{mM} \mathrm{Mgcl} 2$, $1.0 \mu \mathrm{l}$ of $10 \mathrm{mM}$ dNTPs, $0.3 \mu \mathrm{l}$ of Taq polymerase $(5$ Unit/ $\mu \mathrm{l}), 1 \mu \mathrm{l}$ for each primer, $5 \mu \mathrm{L}$ of extracted target DNA and $12.7 \mu \mathrm{L}$ of nuclease free water added to make volume 25 $\mu \mathrm{L}$. The thermal profile was as follows: initial denaturation for
5 minutes at $94^{\circ} \mathrm{C}$ followed by 30 cycles of PCR consisting of denaturation for 1 minute at $94{ }^{\circ} \mathrm{C}$, annealing for 1 minute at $55^{\circ} \mathrm{C}$, extension for $1 \mathrm{~min}$ at $72^{\circ} \mathrm{C}$, followed by final extension for 10 minutes at $72 \circ \mathrm{C}$ [15]. The amplified products mixed with loading dye then loaded in $1.5 \%$ agarose. The electrophoresis was carried out at 1 to $10 \mathrm{~V} / \mathrm{cm}$ of gel. Compared to DNA molecular weight marker, the amplified DNA products were detected using ultra violet transilluminator. Finally, the gel was pictured [25].

\subsection{Sequencing of $P 32$ gene of $S P V$}

PCR products purification and extraction from the gel were carried out in accordance with [25] by using the Wizard $^{\circledR}$ SV Gel and PCR Clean-Up System kit manufacturer's instructions. PCR amplified products were presented to COLORS medical laboratory, Egypt for sequencing DNA by using the same primer used in PCR. Analysis of data obtained in the sequence was done through (http://www.ebi.ac.uk/ Tools/msa/clustalo). The neighbour-joining (N-J) phylogenetic analysis was performed using the alignment output file. After that MegAlign (DNASTAR, Lasergene, Madison, WI, USA) was used to calculate divergence and identity percents. Bioedit software v.7.0.0 was used for molecular analysis of amino acids sequence.

\subsection{Molecular confirmation of SPV using $S Y B R^{\circledR}$ Green Real time-PCR}

Ten samples ( 6 field samples and 4 egg passaged samples) were selected for molecular detection and identification of SPV.

It was carried out in $20 \mu$ reaction mixture using the same primer used in conventional PCR. $1 \mu \mathrm{L}$ of $10 \mu \mathrm{M}$ forward and reverse primers and $5 \mu \mathrm{L}$ of extracted DNA, $9 \mu \mathrm{l}$ PCR grade water and $4 \mu$ l Fast SYBR ${ }^{\circledR}$ Green Master Mix. Non template control (NTC) reaction was used as negative control reaction. The optimum thermal cycling parameters included initial denaturation for 10 minutes at $95 \circ \mathrm{C}$, then 35 cycles of PCR consisting of denaturation for $30 \mathrm{~s}$ at $95 \circ \mathrm{C}$, annealing for $30 \mathrm{~s}$ at $55^{\circ} \mathrm{C}$. Finally, extension for $1 \mathrm{~min}$ at $72^{\circ} \mathrm{C}$, then the amplification plot was obtained $[\mathbf{2 0}, \mathbf{2 5}]$.

\subsection{Histopathological examination}

The field and egg passaged samples were preserved in $10 \%$ neutral formalin. Thin sections were made, haematoxylin and eosin used for staining. Then the histomorphological changes were examined under light microscope. Intracytoplasmic inclusion bodies indicated the positive results [26].

\section{RESULTS}

As explained in (Table 2), from 40 collected samples, the virus was isolated after the $6^{\text {th }}$ passage from $32(80 \%)$ samples include: 16 (80\%) samples from skin nodules and 5 (100\%) samples from lung and lymph node and $3(60 \%)$ samples from liver and tongue. The collected CAMs were congested and thickened with opaque white lesions at site of inoculation in the first three passages. The characteristic pock lesions appeared after the $4^{\text {th }}$ passage and became more clear in the 
form of gray and opaque round lesions after the $6^{\text {th }}$ passage

(Figure 2).

Table 1. Details of the designed oligonucleotide primers of P32 gene of SPV.

\begin{tabular}{|c|c|c|c|c|c|}
\hline Primer pair & Sequence $\left(5^{\prime}-3^{\prime}\right)$ & NO. Bases & $\begin{array}{l}\text { Annealing } \\
\text { temperature }\end{array}$ & $\begin{array}{l}\text { Amplicon } \\
\text { size }\end{array}$ & Reference \\
\hline Forward (B68) & CTAAAATTAGAGAGCTATACTTCTT & 25 & \multirow[b]{2}{*}{$550 \mathrm{C}$} & \multirow[b]{2}{*}{$390 \mathrm{bp}$} & \multirow[b]{2}{*}{ [19] } \\
\hline Reverse (B69) & CGATTTCCATAAACTAAAGTG & 21 & & & \\
\hline
\end{tabular}

Table 2. Comparative results of virus isolation, AGPT and IFAT for 40 prepared collected samples.

\begin{tabular}{|c|c|c|c|c|c|c|}
\hline \multirow[t]{2}{*}{ Sample } & \multirow{2}{*}{$\begin{array}{l}\text { Samples } \\
\text { Collected } \\
(n=40)\end{array}$} & \multirow{2}{*}{$\begin{array}{l}\text { Virus isolation } \\
6^{\text {th }} \text { egg passaged } \\
\text { samples }(n=32)\end{array}$} & \multicolumn{2}{|l|}{ AGPT } & \multicolumn{2}{|l|}{ IFAT } \\
\hline & & & $\begin{array}{l}\text { Field tissue } \\
\qquad(n=17)\end{array}$ & $\begin{array}{l}6^{\text {th }} \text { egg passaged } \\
\text { samples }(n=0)\end{array}$ & $\begin{array}{l}\text { Field tissue } \\
(n=37)\end{array}$ & $\begin{array}{l}6^{\text {th }} \text { egg passaged } \\
\text { samples }(n=33)\end{array}$ \\
\hline Skin & 20 & 16 & 11 & 0 & 20 & 20 \\
\hline Lung & 5 & 5 & 2 & 0 & 5 & 4 \\
\hline Tongue & 5 & 3 & 1 & 0 & 4 & 3 \\
\hline
\end{tabular}

The positive results of AGPT in the form of white precipitation lines were observed within 24-48 hours (Figure 3). The results revealed that 17 (42.5\%) field samples showed positive results include: 11 (55\%) skin nodule samples and 2 (40\%) samples from lung and lymph node and 1 (20\%) sample from liver and tongue, while no line of precipitin detected in any $6^{\text {th }}$ egg passaged samples (Table 2 ).

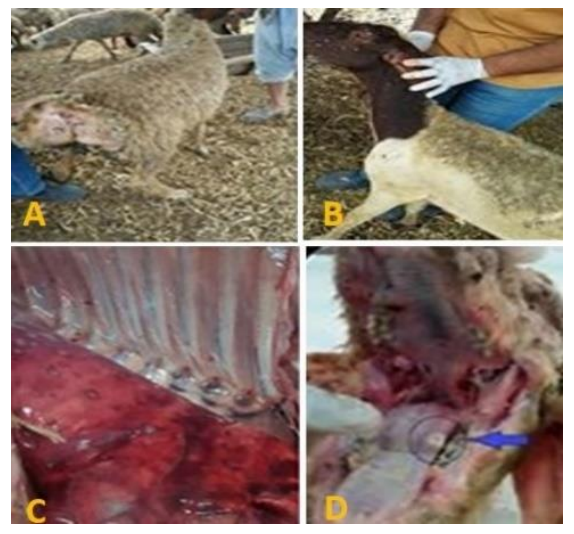

Figure 1. Clinical manifestation and postmortem examination of diseased sheep suspected to be infected with SPV. A: SP suspected sheep showing multiple skin nodules under tail; B: SP suspected sheep showing multiple skin nodules scattered on the face and neck; C: Multiple nodules on the lung of dead lamb suspected to be infected with SPV; D: Multiple nodules on the tongue of dead lamb suspected to be infected with SPV.

With regard to IFAT, the positive results in the form of yellowish green color appeared in 37 (92.5\%) field samples include: 20 (100\%) skin nodule samples (Figure 4 B), 5 (100\%) lung samples and 4 (80\%) samples from liver, lymph node and tongue samples. 33 frozen CAMs prepared sections (after the $6^{\text {th }}$ passage) showed the positive results including $20(100 \%)$ skin nodule samples, 4 (80\%) lung samples and $3(60 \%)$ samples from liver, lymph node and tongue (Table 2). No positive reaction showed in the negative control samples (Figure 4 A).

Analysis of PCR products obtained from amplification reaction of extracted DNA by agarose gel electrophoresis along with DNA Marker was carried out and the 10 selected samples showed positive results of P32 gene amplification with correct size (390bp) as shown in (Figure 5) and real timePCR gave gave threshold cycles (Ct) from 16 to 21 in field samples, while egg passaged samples gave threshold cycles (Ct) from 31 to 37 . The positive control sample gave threshold cycles $(\mathrm{Ct})$ at 13 , whereas the negative control sample gave no reaction (Figure 6).

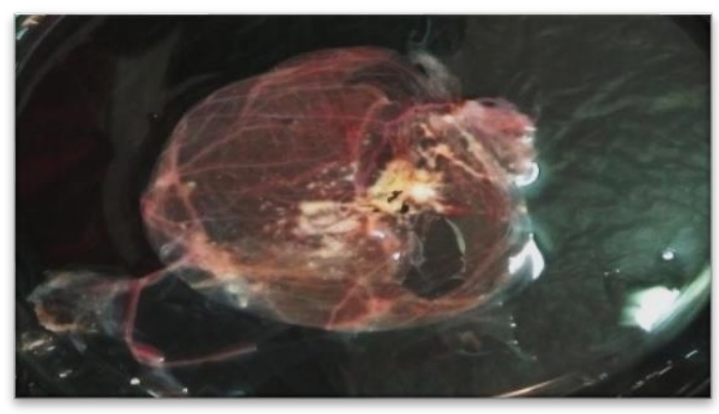

Figure 2. Pock lesion on CAM infected with isolated virus from skin lesion of sheep after) 6th passage).

The alignments of the P32 gene nucleotide sequences (390bp) of SPV isolate compared with other reference CaPVs on the Genbank were carried out followed by phylogenetic tree pattern as shown in (Figure 7) which revealed that our SPV was closely related to Saudi Arabia SPV, 2019. The identity percent of the sequencing of the SPV P32 gene in this study was $99.2 \%$ with Saudi Arabia SPV, 2019. Also, presence of two EcoRV sites (5'GAT/ATC $3^{\prime}$ ) (3`CTA/TAG 5') which are specific for all SPV strains and absent in LSDV. 
Also, intracytoplasmic inclusion bodies indicating the positive results in histopathology were detected in $30(75 \%)$ field samples including 18 (90\%) skin nodule samples, $3(60 \%)$ samples from lung, Liver, lymph node and tongue and in 25 (62.5\%) CAMs samples including 17 (85\%) skin samples, 2 (40\%) samples from lung, Liver, lymph node and tongue (Figure 8).

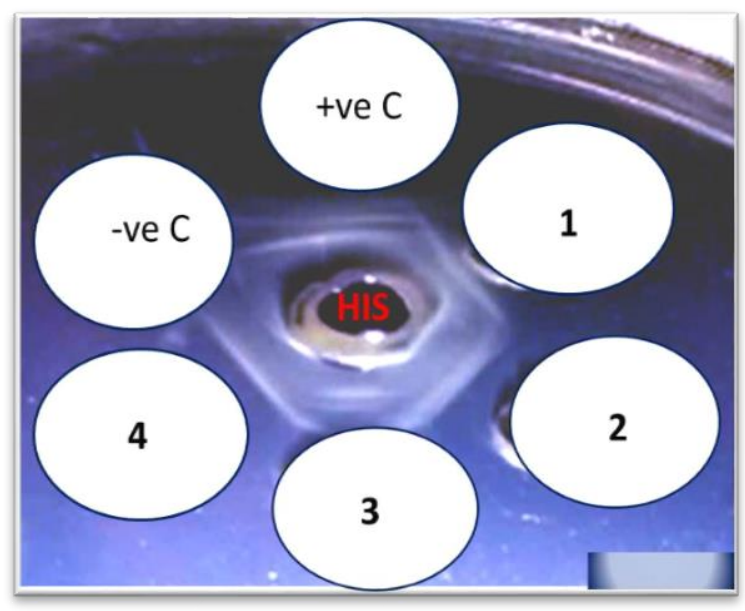

Figure 3. White clear precipitation lines appeared between skin samples and reference SPV hyperimmune sera; Well (1-4): Field skin samples collected from diseased sheep; +ve C: SPV positive control; -ve C: Negative control sample; HIS Well: Hyper immune serum.
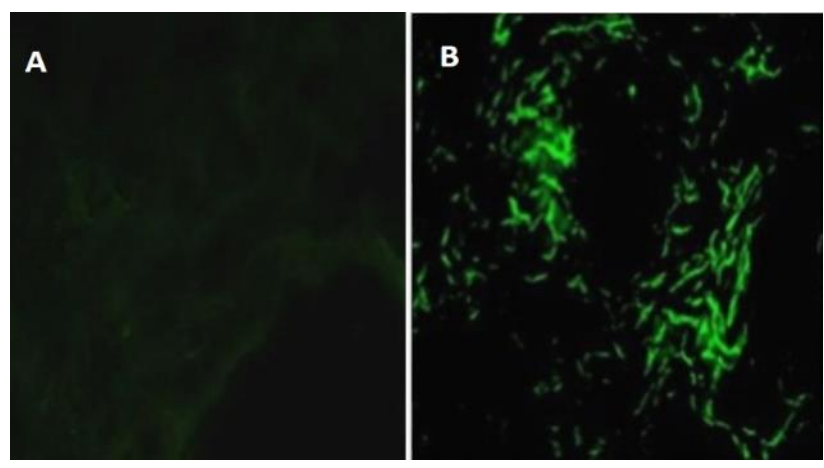

Figure 4. (A) Negative immunofluorescence reaction, no yellowish green color in cryostat section X40; (B) Positive immunofluorescence reaction shows yellowish green color, in skin section $X 40$.

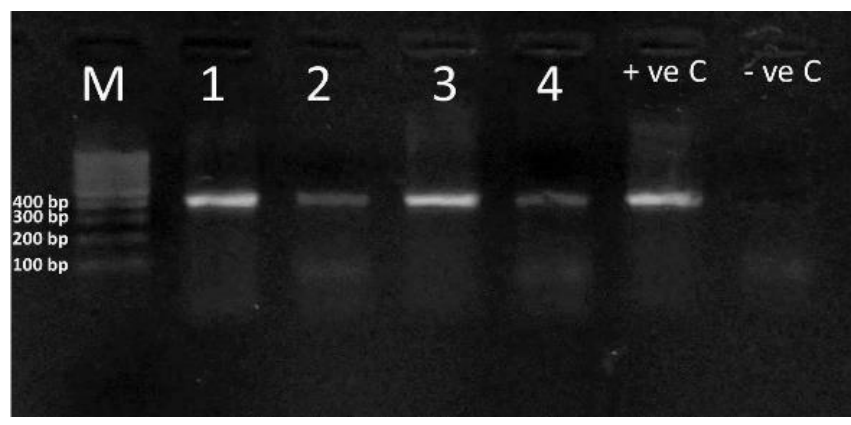

Figure 5. Positive result of molecular identification. Agarose gel electrophoresis of PCR products of P32 gene (390 bp) of SPV. M: DNA marker; Lane 1: The PCR products prepared from collected skin sample; Lane 2: The PCR products prepared from collected skin sample; Lane 3: The PCR products prepared from collected lung sample; Lane 4: The PCR products prepared from collected lung sample; +ve C: The PCR products prepared from standard SPV; -ve C: The PCR products prepared from negative samples.

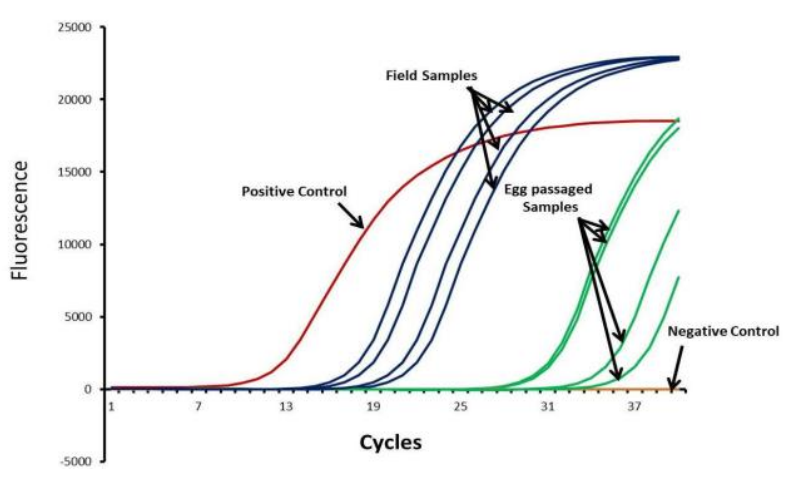

Figure 6. Amplification plot of real time-PCR in SPV molecular identification. Four field samples gave threshold cycles $(\mathrm{Ct})$ from 16 to 21; Four egg passaged samples gave threshold cycles (Ct) from 31 to 37; The positive control sample gave threshold cycles $(\mathrm{Ct})$ at 13 ; The negative control sample gave no reaction.

\section{DISCUSSION}

In this study, trials for isolation as well as, conventional and molecular characterization of SPV from clinically diseased vaccinated sheep in Dakahlia Governorate, Egypt were carried out.

The prevalence of the disease in this study (16.7\%) was lower than previously reported prevalence (23.5) in Sharkia Governorate, Egypt [9]. The variation in prevalence may be attributable to number of the examined animals, sample size, sample place or methods of rearing. Further studies on risk factors for this infection are required in Egypt where sheep are brought up with different ways.

Clinically, lesions reported in diseased sheep were similar to those previously described elsewher [2, 27-30].

Out of 20 collected skin samples, $16(80 \%)$ samples gave positive results after the $6^{\text {th }}$ passage. On the other hand, the internal organs isolation results were: $5(100 \%)$ samples from lung and lymph node and $3(60 \%)$ samples from liver and tongue. The results confirm suitability of ECEs for virus isolation especially in setting with low resources in comparison with cell culture which require well equipped laboratory and skilled staff $[7,31,32]$.

SPV was detected in the field samples by AGPT using refrence SPV antisera. Clear precipitation lines appeared in 17 field samples, while isolates of CAMs showed no precipitation lines $[\mathbf{2 3}, \mathbf{2 4}, \mathbf{3 5}, \mathbf{3 6}]$. AGPT is superior in virus detection in field samples over CAMs samples due to the higher concentration of SPV antigen in field samples than in CAMs of ECEs.

Indirect fluorescent antibody test (IFAT) was carried out on both field and $6^{\text {th }}$ egg passageed samples. The charactristic specific fluorescent color "yellowish green color" recordrd in 37 field samples and in 33 isolates of CAMs [12, 22]. IFAT is superior in virus detection over AGPT as AGPT need high concentration of antigen to be detected.

PCR for partial amplification of the SPV P32 gene followed by gel electrophoresis showed the prescence of the amplified products of positive samples at the correct size (390 
bp). All selected samples were positive by PCR, this finding is in accordance with $[19,37]$. Also, confirmative molecular characterization of the virus using real-time PCR assay was carried out and all selected samples were positive. [38, 39]. The usage of real time-PCR assay for confirmation the diagnosis of SPV is preferable because there is no need for gel electrophoresis following PCR amplification, quasi quantitative method for SPV detection, more rapid, and not much more expensive than conventional PCR except the equipment cost.

The sequences were aligned with the P32 gene sequences available in the GenBank using Clustal Omega (http :/www.ebi.ac.uk/ Tools/ msa / clustal O /).

The obtained result from sequence analysis of the chosen SPV sample showed 99.2\% identity with Saudi Arabia SPV, 2019. Accession no. MN072630.1. This result suggests potential transmission of the virus from Egypt to Saudi Arabia or vice versa, but this need further studies to confirm our hypothesis based on full genomic sequencing and next generation sequencing (NCS).

Histopathological examination was carried out on both field samples and on the sixth passage on CAMs. The positive results indicated by characteristic intracytoplasmic inclusion bodies appeared in 30 field samples and in 25 isolates of CAMs $[30,40,41]$.

Histopathology could be used in diagnosis of sheep pox but need confirmation by immunological or molecular methods

Isolation of SPV from clinically diseased vaccinated sheep is probably due to inappropriate storage and handling of vaccine, the possibility that animals were incubating the disease before vaccination or low efficiency of vaccine may occur in case of strain variation $[42,43]$. Further studies are crucial to understand the genetic relationship between the vaccine strains used in Egypt (Kenyan, Romanian or RM65) and the circulating virus in sheep farms.

\section{Conclusion}

The results of the present study indicate that SPV is existing in sheep flocks in Dakahlia Governorate, Egypt. Molecular characterization of the P32 gene of identified SPV showed close genetic relationship to Saudi Arabia virus, 2019. Further study is crucial to identify the origin of identified SPV as well as its spread pattern analyses.

\section{Conflict of interest statement}

The authors have no conflict of interest

\section{Research ethics committee permission}

The current research work was applied after standards of Research Ethics Committee, Faculty of Veterinary Medicine, Mansoura University.

\section{Authors' contribution}

Hagar E. Ghander conducted the experiment; Mohamed S. EL-Tholoth conducted analytical procedures and helped in writing the manuscript; Sahar E. Abd-El-Rahman and Ali A. Elkenawy revised the manuscript.

\section{REFERENCES}

[1]. Yeruham I, Yadin H, Van Ham M, Bumbarov V, Soham A, Perl S. Economic and epidemiological aspects of an outbreak of sheep pox in a dairy sheep flock. Vet Rec 2007;160:236-237. https://doi.org/10.1136/vr.160.7.236

[2]. Davies FG, Otema C. Relationships of capripoxviruses found in Kenya with two Middle Eastern strains and some orthopoxviruses. Res Vet Sci 1981;31:253-255. https://doi.org/10.1016/S00345288(18)32504-9

[3]. International Committee on Taxonomy of Viruses (ICTV). Sheep pox virus. EC 51, Berlin, Germany, July 2019; Email ratification March 2020 (MSL \#35). https://talk.ictvonline.org/taxonomy/p/taxonomyhistory?taxnode_id=19710286\&src=NCBI\&ictv_id $=19710286$

[4]. Kitching R P, Taylor WP. Clinical and antigenic relationship between isolates of sheep and goat poxviruses. Trop Anim Health Pro 1985;17:64-74. https://doi.org/10.1007/BF02360774

[5]. International Committee on Taxonomy of Viruses (ICTV). Poxviridae dsDNA Viruses. 2011; ICTV ninth report ; 2009 Taxonomy Release. https://talk.ictvonline.org/ictv-reports/ictv_9th_report/dsdna-viruses 2011/w/dsdna_viruses/74/poxviridae

[6 ]. Butterfield WK. Reference Manual, Foreign Animal Disease Courses, Plum Island Animal Disease Center, ARS, USDA. USDA Press 1975.

[7]. Mahmoud MA, Khafagi MH. Detection, identification, and differentiation of sheep poxvirus and goat poxvirus from clinical cases in Giza Governorate, Egypt. Vet World 2016;9:1445 -1449. https://doi.org/10.14202/vetworld.2016.1445-1449

[8]. OIE. Chapter 2.7.13. sheep pox and goat pox. Retrieved 08 July, 2017, from OIE 2017 http://www.oie.int/fileadmin/Home/eng/Health_standards/tahm/2.0 7.13_S_POX_G_POX.pdf.

[9]. Abd-Elfatah EB, El-Mekkawi MF, Bastawecy IM, Fawzi EM. Identification and phylogentic analysis of sheep pox during an outbreak of sheep in Sharkia Governorate, Egypt. Genet Mol Res 2018;17. https://doi.org/10.4238/gmr16039901

[10]. Bhanuprakash V, Venkatesan G, Balamurugan V, Hosamani M, Yogisharadhya R, Chauhan RS, ... \& Singh RK. Pox outbreaks in sheep and goats at Makhdoom (Uttar Pradesh), India: evidence of sheep poxvirus infection in goats. TRANSBOUND EMERG DIS 2010;57,375382. https://doi.org/10.1111/j.1865-1682.2010.01158.x

[11]. Verma S, Verma LK, Gupta VK., Katoch VC, Dogra V, Pal B \& Sharma M. Emerging capripoxvirus disease outbreaks in Himachal Pradesh, a northern state of India. TRANSBOUND EMERG DIS 2011;58,79-85. https://doi.org/10.1111/j.1865-1682.2010.01172.x

[12]. Zhu XL, Yang F, Li HX, Dou XY, Meng XL, Li H, ... \& Cai X. Identification and phylogenetic analysis of a sheep poxvirus isolated from the Ningxia Hui Autonomous Region of China. Genet Mol Res 2013;14:8. https://doi.org/10.4238/2013.May.14.7

[13]. Oguzoglu TC, Alkan F, Ozkul A, Vural SA, Gungor AB, Burgu I. A sheep poxvirus outbreak in Central Turkey in 2003: isolation and identification of capripoxvirus ovis. Vet Res Commun 2006;30:965-971.

[14]. OIE Terrestrial Manual. Chapter 2.7.14- Sheep pox and goat pox 2012. https://www.oie.int/en/scientific-expertise/referencelaboratories/list-of-laboratories/

[15]. Kadam AS, Tembhurne PA, Ingle VC, Kumar PM, Dhok AK, Kalorey DR. Detection of sheep and goat poxviruses by polymerase chain reaction. IJFV 2014;90:48-51.

[16]. Sharma B, Negi BS, Pandey AB, Bandyopadhyay SK, Shankar H, \& Yadav MP. Detection of goat pox antigen and antibody by the counter immunoelectrophoresis test. Trop Anim Health Pro 1988;20,109-113. https://doi.org/10.1007/BF02242237

[17]. Rao TVS, Negi BS \& Bansal MP. Use of purified soluble antigens of sheep poxvirus in serodiagnosis. INDIAN J ANIM SCI 1997;67,642-645.

[18]. Carn VM. An antigen trapping ELISA for the detection of capripoxvirus in tissue culture supernatant and biopsy samples. J Virol Methods 1995;51,95-102. https://doi.org/10.1016/0166-0934(94)00138-7

[19]. Heine HG, Stevens MP, Foord AJ, Boyle DB. A capripoxvirus detection PCR and antibody ELISA based on the major antigen P32, the homolog of the vaccinia virus H3L gene. J Immunol Methods 1999;227:187-196. https://doi.org/10.1016/S0022-1759(99)00072-1 
[20]. Balinsky CA, Delhon G, Smoliga G, Prarat M, French RA, Geary SJ, ... \& Rodriguez LL. Rapid preclinical detection of sheep poxvirus by a realtime PCR assay. J Clin Microbiol 2008;46:438-442. https://doi.org/10.1128/JCM.01953-07

[21]. Chand P. Molecular and immunological characterisation of a major envelope protein of capripoxvirus (Doctoral dissertation, University of Surrey) 1992.

[22]. Davies FG. Characteristics of a virus causing a pox disease in sheep and goats in Kenya, with observations on the epidemiology and control. Epidemiol Infect 1976;76:163-171. https://doi.org/10.1017/S0022172400055066

[23]. Ali AZMM. The use of polymerase chain reaction in diagnosis of sheep pox and goat pox outbreaks (Doctoral dissertation, University of Khartoum) 2005.

[24]. Davies FG, Lund $\mathrm{L}$. The application of fluorescent antibody techniques to the virus of African horse sickness. Res Vet Sci 1974;17:128-130. https://doi.org/10.1016/S0034-5288(18)33720-2

[25]. Viljoen GJ, Nel LH, Crowther JR (Eds.). Molecular diagnostic PCR handbook. Springer science \& business media 2005.

[26]. Lima LG. Manual of histological staining methods of the armed forces institute of pathology. McGraw-Hill Book Company 1968.

[27]. Hailat N, Al-Rawashdeh O, Lafi S, Al-Bateineh Z. An outbreak of sheep pox associated with unusual winter conditions in Jordan. Trop Anim Health Prod 1994;26:79-80. https://doi.org/10.1007/BF02239903

[28]. Buller RM, Palumbo GJ. Poxvirus pathogenesis. Microbiol Mol Biol Rev 1991;55:80-122. https://doi.org/10.1128/MMBR.55.1.80-122.1991

[29]. Saha GR, Nayak NC, Bhowmik MK. Studies on lymphoid lesions of goat pox. Indian J Anim Res 1991;25:1-4.

[30]. Karapinar Z, Ilhan F, Dincer E, Yildirim S. Pathology and phylogenetic analysis of capripoxvirus in naturally infected sheep with sheep poxvirus. Pak Vet J 2017;37:78-84.

[31]. Soad MS, Wafaa AZ, Micheal A, Fayed AA, Taha MM. Studies on sheep and goat poxviruses from naturally infected animals. Assiut Vet Med $J$ 1996;35:29-38.

[32]. Kumar A, Hirpurkar SD, Sannat C, Gilhare VR. Adaptation of capripoxvirus isolate from goats in heterologous cells. J Anim Res 2015;5:671-676. https://doi.org/10.5958/2277-940X.2015.00113.8

[33]. Kitching RP, Hammond JM, Black DN. Studies on the major common precipitating antigen of capripoxvirus. J Gen Virol 1986;67:139-148. https://doi.org/10.1099/0022-1317-67-1-139

[34]. Hajer I, Abbas B, Samra MA. Capripoxvirus in sheep and goats in Sudan. Rev. Elev. Méd. Vét. Pays Trop 1988;41:125-128.

[35]. Parthiban M, Govindarajan R, Manoharan S, Purushothaman V, Daniel joy Chandran N, Koteeswaran A. Comparative sequence analysis of diagnostic PCR amplicons from Indian sheep poxvirus. Vet Arhiv 2005;75:203-209.

[36]. Amal MA, Shahein MA, Hoda AEM. Electrophoretic characterization of sheep poxvirus, goat poxvirus and lumpy skin disease virus. Egypt J Comp Path \& Clinic Path 2008;21:15-30.

[37]. Mondal B, Hosamani M, Dutta TK, Senthilkumar VS, Rathore R, Singh RK. An outbreak of sheep pox on a sheep breeding farm in Jammu, India. Rev Sci Tech- Off Int Epizoot 2004; 23:943-950. https://doi.org/10.20506/rst.23.3.1536

[38]. Lamien CE, Lelenta M, Goger W, Silber R, Tuppurainen E, Matijevic M, ... \& Diallo A. Real time-PCR method for simultaneous detection, quantitation and differentiation of capripoxviruses. J Virol Methods 2011;171:134-140. https://doi.org/10.1016/j.jviromet.2010.10.014

[39]. Tian H, Wu J, Chen Y, Zhang K, Shang Y, Liu X. Development of a SYBR green real-time PCR method for rapid detection of sheep poxvirus. Virol J 2012;9:291. https://doi.org/10.1186/1743-422X-9-291

[40]. Gulbahar MY, Cabalar M, Gul Y, Icen H. Immunohistochemical detection of antigen in lamb tissues naturally infected with sheep poxvirus. J Vet Med B 2000;47:173-181. https://doi.org/10.1046/j.14390450.2000.00321.x

[41]. Aldaiarov N, Stahel A, Nufer L, Jumakanova Z, Tulobaev A, Ruetten M. Outbreak of sheep pox in farmed sheep in Kyrgystan: histological, eletron microscopical and molecular characterization. Schweiz Arch Tierh 2016;158:529-532. https://doi.org/10.17236/sat00076

[42]. Ayelet G, Abate Y, Sisay T, Nigussie, H, Gelaye E, Jemberie S, \& Asmare K. Lumpy skin disease: preliminary vaccine efficacy assessment and overview on outbreak impact in dairy cattle at Debre Zeit, central Ethiopia. Antivir Res 2013; 98,261-265. https://doi.org/10.1016/j.antiviral.2013.02.008
[43]. Gelaye E, Belay A, Ayelet G, Jenberie S, Yami M, Loitsch A, ... \& Lamien CE. Capripox disease in Ethiopia: genetic differences between field isolates and vaccine strain, and implications for vaccination failure. Antivir Res 2015; 28-35. https://doi.org/10.1016/j.antiviral.2015.04.008 